\title{
UNIVERZITNÉ SPIN-OFF FIRMY: AKÉ SÚ? (PRÍPADOVÁ ŠTÚDIA SLOVENSKEJ POLNOHOSPODÁRSKEJ UNIVERZITY V NITRE)
}

\author{
Jana Jarábková, Marcela Chreneková
}

\begin{abstract}
The transfer of research and development results into application sphere takes place in the university environment in a variety of ways. One of them is the establishment of a spin-off firm. From general definition of a spin-off, it is an independent firm founded to commercialize university knowledge. The understanding of spin-off firms and spin-off processes in the literature differs significantly. The aim of the paper is to identify existing and potential spin-off companies in the environment of the Slovak University of Agriculture in Nitra, to describe their specificities in comparison to orthodox defined spin-off firms, to evaluate the conditions for their establishment, to examine the process of commercialization of intellectual property from the birth of the idea to the establishment of own firm or technology licensing. On the examples of selected spin-off firms, we analyze the personal motives and barriers that influenced the founders in the development of technology and the commercialization of research results and the key factors that influenced the founder in the development and commercialization of technology. The contribution is based on case studies of three spin-off firms founded by university staff, in order to exploit the knowledge produced by university activities with a prospect of profiting.
\end{abstract}

Keywords: technology transfer, commercialization of research results, university spin-offs

\section{Úvod}

Prenos výsledkov výskumu a vývoja do praxe prebieha v univerzitnom prostredí rôznymi spôsobmi. Často sa realizuje formou zverejnenia napr. v publikácii, prednáškou, na konferencii, alebo prostredníctvom poskytovania služieb a konzultácií, výskumom na objednávku, predajom licencií (práva $\mathrm{k}$ užívaniu) alebo tiež založením spin-off firmy (Klímová, 2013). Spin-off firmy umožňujú premenit' poznatky, ktoré vznikli na univerzite v rámci výskumu do predaja schopného resp. komercionalizovatel'ného produktu alebo služby (Pirnayet al.,2003; Djokovic, Souitaris, 2008; Bathelt et al., 2010, Soetanto, Van Geenhuizen, 2015). Chápanie spin-off firiem v teórii i praxi je vel'mi rôzne (tab. 1), závisí od účelu vymedzenia, vnútorných predpisov univerzít a výskumných inštitúcií a chápania spin-off v rôznych krajinách. Podl'a autorov (Bernardt et al., 2002) je spin-off firmou jednotlivca alebo skupiny osôb, ktoré opustili materskú 
organizáciu s úmyslom začat' nový, samostatný podnikatel'ský zámer postavený na výsledkoch svojho výskumu. Materská organizácia podporuje spin-off firmu tým, že tento prenos vedomostí, schopností a zručností umožní, a to vrátane možnosti vloženia priamych prostriedkov do jej založenia. Často dochádza $\mathrm{k}$ zamieňaniu pojmov spin-off a spin-out. Noskovič (2018) uvádza, že spin- off firma je spoločnost', ktorú založila vedecko-výskumná inštitúcia za účelom komercializácie určitých výsledkov vedy a výskumu (priemyselného vlastníctva), pritom spolumajitel'mi firmy sú univerzita, pôvodcovia (zamestnanci univerzity) a investor. Spin-out potom chápe ako spoločnost', ktorú založil pôvodca alebo spolupôvodcovia za účelom komercializácie výsledkov vedy a výskumu, a ktorej univerzita udelila licenciu na ich využívanie. V odbornej literatúre sa rozlišujú d’alej rôzne typy spin-off firiem napr. podl'a väzby k zakladatel'ovi, majetkového podielu, výsledku činnosti, lokalizácie, právnej firmy, využívania znalostí, spôsobu nadobudnutia duševného vlastníctva, podiel pôvodcu duševného vlastníctva, zamestnaneckého vzt'ahu zakladatel'a, využívanie zariadení univerzity, finančnej spätnej väzby a tvorby siet’ových efektov (Čorejová, Rostášová, 2016).

Tab. 1: Vymedzenie spin-off firmy

Table 1: Definition of spin-off firm

\begin{tabular}{|l|c|}
\hline \multicolumn{1}{|c|}{ Vymedzenie spin-off firmy } & Zdroj/autori \\
\hline $\begin{array}{l}\text { Firma, ktorá vznikla odlúčením zamestnancov zo } \\
\text { znalostnej inštitúcie (vysokej školy, strediska výskumu a } \\
\text { vývoja, technologickej firmy). Pritom pôvodná znalostná } \\
\text { inštitúcia môže mat' v tejto spin-off firme majetkový } \\
\text { podiel. Ďalšou charakteristickou črtou spin-off firmy je, } \\
\text { že využiva hmotný a nehmotný majetok iného právneho } \\
\text { subjektu k zahájeniu svojho podnikania. }\end{array}$ & Rydvalová, 2011 \\
\hline $\begin{array}{l}\text { Nezávislá firma založená s cielom premenit' univerzitné } \\
\text { znalosti a výskum do predaja schopného produktu alebo } \\
\text { služby. }\end{array}$ & $\begin{array}{r}\text { Pirnayet al., 2003; } \\
\text { Djokovic, Souitaris, } \\
\text { 20010, Sathelt et al., } \\
\text { Geenhuizen M., } \\
2015\end{array}$ \\
\hline $\begin{array}{l}\text { Univerzitná spin-off firma je nová spoločnost' vytvorená } \\
\text { z univerzity, s ciel'om využitia znalostí } \\
\text { vyprodukovaných činnost'ou na univerzite, s } \\
\text { perspektívou dosiahnutia zisku. }\end{array}$ & Janovčík, Herčko, \\
\hline $\begin{array}{l}\text { Spin-off je spoločnost', ktorú založila vedecko-výskumná } \\
\text { inštitúcia za účelom komercializácie výsledkov výskumu } \\
\text { a vývoja. }\end{array}$ & Noskovič, 2018 \\
\hline
\end{tabular}




\begin{tabular}{|c|c|}
\hline $\begin{array}{l}\text { Spin-off je firma, ktorá vznikla odčlenením z materskej } \\
\text { organizácie, ktorou je univerzita alebo akademická } \\
\text { inštitúcia. Je samostatným subjektom nezávislým na } \\
\text { materskej organizácii. Využíva poznatky akademického } \\
\text { výskumu a je zameraná na generovanie zisku } \\
\text { a komercializáciu technológií. }\end{array}$ & $\begin{array}{r}\text { Pattnaik, Pandey, } \\
2014\end{array}$ \\
\hline $\begin{array}{l}\text { Nová firma alebo organizácia, ktorá využíva výsledky } \\
\text { univerzitného výskumu. }\end{array}$ & $\begin{array}{r}\text { Klofsten, Jones- } \\
\text { Evans, } 2000 .\end{array}$ \\
\hline $\begin{array}{l}\text { Spoločnost' založená univerzitnými učitel'mi, } \\
\text { výskumníkmi alebo doktorandmi a študentmi za účelom } \\
\text { komercializácie výsledkov výskumu, ktoré vznikli na } \\
\text { univerzite. }\end{array}$ & Bellini et al., 1999. \\
\hline $\begin{array}{l}\text { Inovatívna firma, založená za účelom využitia a rozvoja } \\
\text { duševného vlastníctva akademickej alebo } \\
\text { vedeckovýskumnej inštitúcie až do formy produktu } \\
\text { (výrobku alebo služby) uplatnitel’nej na trhu. Duševné } \\
\text { vlastníctvo je firme poskytnuté prostredníctvom } \\
\text { licenčnej zmluvy alebo predajom, pričom inštitúcia môže } \\
\text { (ale aj nemusí) získat' v spin-off majetkový podiel. Na } \\
\text { činnosti firmy sa zvyčajne podiel'ajú aj pôvodcovia } \\
\text { príslušného duševného vlastníctva. Spravidla ide o malé } \\
\text { firmy s vysokým rastovým potenciálom. }\end{array}$ & $\begin{array}{r}\text { Čorejová, } \\
\text { Rostášová, } 2016\end{array}$ \\
\hline $\begin{array}{l}\text { Firma založená zamestnancom alebo skupinou } \\
\text { zamestnancov, ktorí zanechajú pôvodnú organizáciu za } \\
\text { účelom založenia právne a technicky samostatnej } \\
\text { jednotky, pričom spin-off firma je podporovaná } \\
\text { univerzitou prinajmenšom v štartovacej fáze }\end{array}$ & Čorej a kol., 2006 \\
\hline
\end{tabular}

\section{Teoreticko-metodické východiská}

Pre účely skúmania spin-off firiem v slovenských podmienkach použijeme flexibilnejšie vymedzenie spin-off firmy, tak ako vnímajú spin-off firmu autori: Pirnayet al., 2003; Djokovic, Souitaris, 2008; Bathelt et al., 2010, Janovčík, Herčko, Klacková, 2014, Noskovič, 2018, Bellini et al., 1999 a Čorej a kol., 2006.

Ciel'om príspevku je identifikovat' existujúce a potenciálne spin-off firmy $\mathrm{v}$ prostredí Slovenskej pol'nohospodárskej univerzity $\mathrm{v}$ Nitre, ich špecifiká v porovnaní s ortodoxne vymedzenými spin-off firmami, podmienky pre ich založenie, preskúmat' proces komercializácie duševného vlastníctva od zrodu myšlienky až po založenie vlastnej firmy alebo predaj licencie existujúcej firme. $\mathrm{Na}$ príkladoch vybraných spin-off firiem zmapujeme osobné motívy a bariéry, ktoré ovplyvnili pôvodcov pri vývoji technológie a komercializácii výsledkov výskumu a kl'účové faktory, ktoré ovplyvnili pôvodcu (zamestnanca univerzity) pri 
vývoji a komercializácii technológie. Príspevok vychádza z prípadových štúdií troch spin-off firiem, ktoré vznikli odčlenením od univerzity resp. založením novej firmy zamestnancom univerzity, s ciel'om využitia znalostí vyprodukovaných činnostou na univerzite, s perspektívou dosiahnutia zisku (tab. 2). Prípadové štúdie vznikli na základe údajov získaných z databáz firiem FinStat, Obchodného registra SR, výročných správ o výsledkoch hospodárenia, webových stránok firiem a osobných interview s pôvodcami duševného vlastníctva, zamestnancami SPU a manažérmi firiem. Interview sa realizovali na základe spoločnej metodiky, v rámci projektu UNIREG (Univerzity a ekonomický rozvoj regiónov) č. APVV-14-0512.

Tab. 2: Opis vybraných spin-off firiem

Table 2: Description of selected spin-off firms

\begin{tabular}{|c|c|c|c|c|}
\hline Firma & $\begin{array}{l}\text { Založenie } \\
\text { firmy }\end{array}$ & $\begin{array}{c}\text { Vzt'ah k SPU } \\
\text { v čase } \\
\text { založenia } \\
\text { firmy }\end{array}$ & Vlastníctvo & Oblast' \\
\hline $\begin{array}{l}\text { Spin-off firma } \\
\text { (SAMO Europe } \\
\text { s.r.o.) s vkladom } \\
\text { duševného } \\
\text { vlastníctva na } \\
\text { základe } \\
\text { licenčnej } \\
\text { zmluvy }\end{array}$ & 2017 & $\begin{array}{r}\text { Zamestnanci } \\
\text { SPU }\end{array}$ & Súkromné & $\begin{array}{r}\mathrm{ICT}, \\
\text { marketing }\end{array}$ \\
\hline $\begin{array}{l}\text { ENVI-GEOS } \\
\text { Nitra s.r.o }\end{array}$ & 1993 & $\begin{array}{r}\text { Zamestnanec } \\
\text { SPU }\end{array}$ & $\begin{array}{r}\text { Súkromné } \\
(100 \% \\
\text { vlastník } \\
\text { bývalý } \\
\text { zamestnanec } \\
\text { SPU) }\end{array}$ & $\begin{array}{r}\text { Zber } \\
\text { a recyklácia } \\
\text { odpadu }\end{array}$ \\
\hline $\begin{array}{l}\text { Vysokoškolsky } \\
\text { pol'nohospodárs } \\
\text { ky podnik SPU } \\
\text { s.r.o. }\end{array}$ & $\begin{array}{r}2003 \\
\text { (pôvod. } \\
1955)\end{array}$ & $\begin{array}{r}\text { Organizačná } \\
\text { súčast' } \\
\text { univerzity }\end{array}$ & $\begin{array}{r}\text { Štátne }(100 \\
\% \text { vlastník } \\
\text { SPU) }\end{array}$ & $\begin{array}{r}\text { Zmiešané } \\
\text { hospodárstvo }\end{array}$ \\
\hline
\end{tabular}

Zdroj: Obchodný register SR, interview so štatutárom firmy a pôvodcom patentu 
Tab. 3: Osobitosti spin-off firiem (na príklade SPU v Nitre)

Table 3: Specifics of spin-off firms (based on the example of SUA in Nitra)

\begin{tabular}{|c|c|c|}
\hline Spin-off firma & Špecifické znaky spin-off & $\begin{array}{c}\text { Odlišnosti od } \\
\text { tradičných spin-off } \\
\text { firiem }\end{array}$ \\
\hline $\begin{array}{l}\text { Spin-off firma s } \\
\text { vkladom duševného } \\
\text { vlastníctva na základe } \\
\text { licenčnej zmluvy } \\
\text { Tržby 2016: } 4462 \text { Eur } \\
\text { Počet zamestnancov: } \\
0\end{array}$ & $\begin{array}{r}\text { - majetková účast' univerzity } 90 \%, \\
\text { • využitie výsledkov } \\
\text { vedeckovýskumnej činnosti až do } \\
\text { formy produktu realizovaného na } \\
\text { trhu } \\
\text { - duševné vlastníctvo je chránené } \\
\text { patentom } \\
\text { - duševné vlastníctvo je firme } \\
\text { poskytnuté prostredníctvom } \\
\text { licenčnej zmluvy } \\
\text { - predmetom činnosti firmy je } \\
\text { d'alší vývoj technológie, predaj } \\
\text { technológie a výroba zariadení }\end{array}$ & $\begin{array}{r}\text { - nie sú dohodnuté } \\
\text { definitívne podmienky } \\
\text { riadnej licenčnej } \\
\text { zmluvy }\end{array}$ \\
\hline $\begin{array}{l}\text { ENVI-GEOS Nitra } \\
\text { s.r.o } \\
\text { Tržby 2016: 5,4 mil. } \\
\text { Eur } \\
\text { Počet zamestnancov: } \\
130\end{array}$ & $\begin{array}{r}\text { - firma založená zamestnancom } \\
\text { univerzity za účelom aplikácie a } \\
\text { využitia výsledkov } \\
\text { vedeckovýskumnej činnosti až do } \\
\text { formy produktu realizovaného na } \\
\text { trhu }\end{array}$ & $\begin{array}{r}\text { bez majetkovej } \\
\text { účasti univerzity } \\
\bullet \text { použivaná } \\
\text { technológia ani } \\
\text { výsledný produkt nie } \\
\text { je chráneným } \\
\text { predmetom duševného } \\
\text { vlastníctva }\end{array}$ \\
\hline $\begin{array}{l}\text { Vysokoškolsky } \\
\text { pol'nohospodársky } \\
\text { podnik SPU s.r.o. } \\
\text { Tržby 2016: } 3,8 \text { mil. } \\
\text { Eur } \\
\text { Počet zamestnancov: } \\
76\end{array}$ & $\begin{array}{r}\bullet 100 \text { \% majetková účast' } \\
\text { univerzity } \\
\text { - firma založená za účelom } \\
\text { aplikácie a využitia výsledkov } \\
\text { vedeckovýskumnej činnosti až do } \\
\text { formy produktu realizovaného na } \\
\text { trhu } \\
\text { - testovacie pracovisko - } \\
\text { experimentálne overovanie } \\
\text { výsledkov vo výrobe }\end{array}$ & $\begin{array}{r}\bullet \text { duševné } \\
\text { vlastníctvo nie je } \\
\text { poskytnuté firme } \\
\text { prostredníctvom } \\
\text { licenčnej zmluvy ani } \\
\text { na základe predaja } \\
\text { - na činnosti firmy } \\
\text { sa priamo nepodielajú } \\
\text { pôvodcovia duševného } \\
\text { vlastníctva }\end{array}$ \\
\hline
\end{tabular}

Zdroj: Interview so štatutármi firiem a pôvodcom patentu, FinStat, 2017

\section{Genéza komercializácie duševného vlastníctva na príklade vybraných spin-off firiem}

Základným predpokladom pre založenie firmy, ktorá umožní transfer univerzitných poznatkov do praxe je originálna myšlienka - nápad, ktorý má komerčný potenciál. V prípade vybraných firiem sa zrod takejto myšlienky viaže 
na výskumnú činnost', ktorú realizovali zamestnanci univerzity na svojich pracoviskách individuálne alebo vo výskumných tímoch (Firma 1 a Firma 2). Kým vo firme 1 súvisel výskum $\mathrm{s}$ riešenou dizertačnou prácou a pôvodcom myšlienky bol študent tretieho stupňa štúdia, vo firme 2 bol pôvodcom pedagogický pracovník, ktorý úzko spolupracoval s praxou v oblasti odpadového hospodárstva.

Vo firme 1 (obr. 1) pôvodca patentu spolu s d'alšími dvoma zamestnancami SPU spolupracoval na vývoji technických zariadení s externými firmami. V roku 2014 uzavrela univerzita na podnet pôvodcov zmluvu s CVTI o poskytovaní expertných podporných služieb. Pred vývojom technológie realizoval pôvodca v spolupráci s SPU odhad komerčného potenciálu a technologické a metodické rešerše. CVTI poskytlo pôvodcom duševného vlastníctva podporu na ochranu duševného vlastníctva. Podmienkou poskytnutia podpory bolo vyhotovenie prototypu zariadenia a jeho testovanie, ktoré zaistili pôvodcovia z vlastných zdrojov. $\mathrm{V}$ priebehu procesu registrácie patentovej prihlášky dostali pôvodcovia ponuku od priameho investora $\mathrm{k}$ predaju technológie, investor však $\mathrm{z}$ dôvodu vysokého rizika investície požadoval príliš vysoký podiel na zisku a pôvodcovia ponuku odmietli. V roku 2017 bola uzavretá zmluva o uzavretí budúcej licenčnej zmluvy medzi SPU, CVTI (budúci poskytovatelia licencie) a spin off firmou SAMO Europe s.r.o. Pôvodcovia a firma už počítajú so spoluprácou na d'alšom vývoji. Predpokladá sa uzavretie dodatočných zmlúv (rámcová spolupráca/poskytovanie služieb). Impulzom pre založenie firmy 2 (obr. 2) bolo získanie širokospektrálnych poznatkov z oblasti odpadového hospodárstva (nie jeden konkrétny poznatok). Firma vo svojich začiatkoch poskytovala odborné poradenstvo, nezačínala výrobou, recykláciou... „obce v regióne mali spoločný problém, ktorý nemal kto za nich riešit'“.

Založenie firmy nebol výsledok jednej výskumnej úlohy, ale aplikovanie poznatkov z viacročného aj základného výskumu. , $V$ zahraniči bežne fungujú združenia, princípy solidarity medzi obcami pri zbere a zvoze odpadu. Najskôr poradenstvo, potom technológie (zhutňovanie odpadu) spracovanie a zhodnocovanie odpadu. " Zakladatel' firmy, pedagóg, zamestnanec univerzity získal prvé informácie a skúsenosti z oblasti odpadového hospodárstva počas študijných pobytov a stáží v Nemecku a Rakúsku, v 90-tych rokoch. Tieto skúsenosti mali viest' $\mathrm{k}$ inovácii študijných programov na SPU (FZKI). Okrem vzdelávania našli svoje uplatnenie aj pri realizácii prevažne základného výskumu zameraného na odpadové hospodárstvo, riešení kvalifikačných prác, v spolupráci $\mathrm{s}$ praxou - obcami v regióne pri identifikácii ich problémov a hl'adaní spoločných riešení a v poradenskej činnosti pre prax. To viedlo, v roku 1993, k založeniu samostatnej firmy ENVI-GEOS Nitra s.r.o., ktorá bola pôvodne zameraná na poradenstvo v oblasti ekológie a v roku 1998 k založeniu d'alšej firmy ENVIGEOS RECYKLING, s.r.o. zameranej na recykláciu triedených odpadov. Podl'a vyjadrenia majitel'a firmy „používané technológie nebolo potrebné chránit' duševným vlastníctvom, nakol'ko tieto boli nové len v podmienkach SR a boli 
implementované vo verejnom záujme“. Pôvodne firmu zakladali 4 spoluvlastníci, neskôr firmu prevzal do vlastníctva 1 vlastník. Firma ENVI-GEOS Nitra s.r.o. postupne rozširovala svoje podnikatel'ské aktivity, inovovala strojové vybavenie a technológie spracovania odpadu, rozširovala špecializované služby pre firmy, obce a občanov. Je stabilnou firmou. V súčasnosti dosahuje tržby 5,4 mi. EUR/rok (2016) a zamestnáva 130 zamestnancov. $100 \%$ vlastníkom firmy je osoba, ktorá bola do roku 2010 zamestnancom SPU. Momentálne univerzita nemá žiadny majetkový podiel v existujúcej firme. V období vzniku firmy bolo podnikanie, ktoré súviselo $\mathrm{s}$ výskumnou činnostou na univerzite skôr obmedzované a vyžadovalo súhlas vedenia univerzity.

Obr. 1: Spin-off firma (SAMO Europe s.r.o.) s vkladom duševného vlastníctva na základe licenčnej zmluvy (Firma 1) Figure 1: Spin-off firm (SAMO Europe s.r.o.) (Firm 1)

Zrod myšlienky - pôvodca patentu riešenie dizertačnej práce "využitie neuromarketingu vo vizuálnom merchandisingu potravín"

(2012-2015) na Katedre marketingu a obchodu FEM,

Spolupráca s odborníkom na ICT na vývoji technológie

Odhad komerčného potenciálu a technické
rešerše (2013-2014) - požiadavka CVTI-
vypracoval pôvodca - právnu podporu
poskytla SPU

Vývoj prototypov (2014)-pôvodcovia na vlastné náklady

Prevod predmetu duševného vlastníctva na SPU (2014)

Registrácia 2 patentov (2015) - podanie prihlášky s právnou a finančnou podporou CVTI

Príprava licenčnej zmluvy a komercializácia (2016) - TC SPU s podporou CVTI

Predaj technológie spin-off firme prostredníctvom licenčnej zmluvy (2017)
Obr. 2: ENVI-GEOS Nitra s.r.o.

(Firma 2)

Figure 2: ENVI-GEOS Nitra s.r.o. (Firm 2)

Zrod myšlienky - skúsenosti získané počas zahraničných pobytova stáží, nekoncepčné odpadové hospodárstvo obcí v regióne

Výskum v oblasti odpadového hospodárstva - na pracovisku Katedra meliorácií, neskôr na Katedre krajinného inžinierstva

Riešenie kvalifikačných prác zameraných na identifikáciu problémov odpadového hospodárstva obcí v regióne

Intenzívna komunikácia s manažmentom obcí - diskusie, semináre o problémoch v odpadovom hospodárstve obcí, potreba systémových riešení.

Založenie spin off firmy ENVI-GEOS

Nitra s.r.o. (1993) - poradenstvo v oblasti ekológie, výskum a vývoj v oblasti prírodných vied - 3 spoluvlastníci

Založenie d'alšej firmy ENVI-GEOS

RECYKLING, s.r.o. (1998)-podnikanie

v oblasti nakladania s odpadmi, recyklácia triedených odpadov - 4 spoluvlastníci

Rozšírenie predmetu podnikania ENVI-

GEOS Nitra s.r.o. (2004) - podnikanie v oblasti nakladania s odpadmi, odstraňovanie odpadu

Zdroj: Interview so štatutármi firiem a pôvodcom patentu 
Špecifickým príkladom firmy (obr. 3), ktorá dlhodobo aplikuje v praxi výstupy vedecko-výskumnej činnosti v oblasti pol'nohospodárstva, ktorých pôvodcami sú výskumníci SPU a teda je zároveň experimentálnym pracoviskom, je Vysokoškolský pol'nohospodársky podnik SPU, s.r.o. (Firma 3).

Obr. 3: Vysokoškolsky pol'nohospodársky podnik SPU s.r.o. (Firma 3)

Figure 3: Agricultural Enterprise, SUA (Firm 3)

Zrod myšlienky založit' firmu (1955) - reakcia na potrebu zabezpečit praktickú výučbu pre študentov a realizovat' účelovú činnost'

Výskum v oblasti pol'nohospodárstva - experimentálne pracovisko Vysokej školy pol’nohospodárskej v Nitre, riešenie výskumných úloh - testovanie výsledkov, riešenie záverečných prác študentov a realizácia odborných praxí počas štúdia

\begin{tabular}{|c|}
$\begin{array}{c}\text { Aplikácia výsledkov výskumu vo Vysokoškolskom } \\
\text { pol'nohospodárskom podniku prispela k rastu výkonov v } \\
\text { rastlinnej a živočíšnej výrobe VPP - komercializácia výsledkov } \\
\text { výskumu }\end{array}$ \\
\hline $\begin{array}{c}\text { Poradenská činnost' pol'nohospodárskym podnikom pri } \\
\text { riešení problémov spojených s technologiou, organizáciou a } \\
\text { ekonomikou pol'nohospodárstva }\end{array}$ \\
$\begin{array}{c}\text { Zmena právnej formy firmy (2003) z príspevkovej organizácie } \\
\text { MŠSR na s.r.o - zlepšila dostupnost' zdrojov financovania a } \\
\text { zjednodušila riadenie podniku }\end{array}$ \\
\hline
\end{tabular}

Zdroj: Interview so štatutármi firiem a pôvodcom patentu

Základ pre založenie samostatnej firmy vytvoril Školský pol’nohospodársky podnik (ŠPP pri Vysokej škole pol'nohospodárskej). Jeho hlavnou úlohou bolo zabezpečenie účelovej činnosti na úseku výchovno-vzdelávacieho procesu. O. i. sa podiel'al aj na vedecko-výskumnej činnosti vysokej školy a slúžil ako experimentálne pracovisko na overovanie výsledkov výskumnej činnosti školy vo výrobe. V období 80 -tych rokov hospodáril podnik na 2500 ha pol'nohospodárskej pôdy a pod riadenie podniku patril aj výskumno-výukový pol’ovný revír (2400 ha) a rybné hospodárstvo. $\mathrm{V}$ tomto období sa kládol dôraz na „hmotné realizačné výstupy“ v oblasti biológie, agrochémie a mechanizácie, ktoré prispievali $\mathrm{k}$ zefektívňovaniu pol'nohospodárskej výroby. Príkladom bolo napr. vyvinutie preparátu AVARTÍN. Jeho aplikácia umožnila likvidovat' hromadné ochorenia včelstiev. Účinnost' preparátu bola po prvý-krát overená v podmienkach VPP. Ďalším príkladom hmotného realizačného výstupu bolo vyvinutie zariadenia na 
úpravu mechanizmov na zber strukovín, ktoré minimalizovali straty a poškodenie zrna. Tieto úlohy sa riešili sa na objednávku pol’nohospodárskych podnikov, pričom objednávatelia úloh boli často tvorivými členmi riešitel'ských kolektívov. V roku 2000 sa $\mathrm{v}$ areáli VPP SPU v Kolíňanoch vybudovalo demonštračné bioplynové zariadenie. Vybudovanie zariadenia bolo realizačným výstupom medzinárodného výskumného projektu INCO COPERNICUS „Bioplynové technológie pre regeneratívnu dodávku energie vo východnej Európe“. Zariadenie slúži na prevádzkové overovanie laboratórne získaných poznatkov z oblasti produkovania energie z biomasy pri riešení d’alších medzinárodných výskumných projektov (napr. v rámci 5. RP EÚ EFFECTIVE a AMONCO).

V roku 2003, po nadobudnutí účinnosti Zákona o vysokých školách sa zmenila forma hospodárenia ŠPP a podnik majetkovo, právne a ekonomicky splynul s univerzitou. Komplikované riadenie a ako aj otvárajúce sa možnosti financovania podniku (fondy EÚ) si vyžiadali zmenit’ právnu formu podniku na s.r.o. (v $100 \%$ vlastníctve univerzity) Vysokoškolský pol'nohospodársky podnik SPU s.r.o. v Kolíňanoch. Hlavný zámer podniku zostal zachovaný, „okrem podnikania na pôde, je ním i nad’alej vytváranie podmienok a poskytovanie služieb $v$ oblasti praktickej výučby, výskumu, vývoja a realizácie odborných praxí študentov SPU v Nitre s cielom komplexnej prípravy absolventov pre ich úspešné uplatnenie na trhu práce".

\section{Osobné motívy a bariéry, ktoré ovplyvnili pôvodcov pri vývoji technológie a komercializácii výsledkov výskumu}

K založeniu firmy 1 motivovali pôvodcu patentu predovšetkým ,,zápal pre problematiku neuromarketingu, očakávaný finančný prospech a naplnenie cielov dizertačnej práce. V súčasnosti, už ako pedagóga, na univerzite ho motivujú skúsenosti, ktoré využiva pri výuke (značné), a vbudúcnosti podnikatel'ské príležitosti “. Pôvodca, dnes pedagóg sa snažil už počas štúdia podnikat'. Vychádzal z prieskumu preferencií spotrebitel’ov a na základe vedeckých nástrojov si zvolil predmet podnikania, no neuspel. To bol impulz k vývoju technológie, ktorá by bola pre trh atraktívna. V súčasnosti pôsobí na SPU ako vysokoškolský pedagóg na Katedre marketingu a obchodu. $\mathrm{V}$ rámci vzdelávania sa venuje problematike marketingu a manažmentu obchodnej firmy.

Majitel' firmy 2 svoje skúsenosti a poznatky o odpadoch získané v rámci viacerých vzdelávacích aktivít a stáží v zahraničí v 90- tych rokoch aplikoval, v tom čase pedagóg SPU, do výskumu realizovaného na katedre. Výsledky výskumu overoval riešitel'ský tím z Katedry meliorácií prostredníctvom riešenia záverečných prác $\mathrm{v}$ konkrétnom priestore $-\mathrm{v}$ obciach Nitrianskeho regiónu. To podnietilo vel'mi prakticky orientovanú spoluprácu s komunálnou sférou: „Zistili sme, že obce $v$ regióne majú vel’mi podobné problémy a každá si ich rieši individuálne. Zorganizovali sme seminár pre starostov obci a ujasnili sme si 
problém a hladali sme spoločné systémové riešenie pre všetky obce. Navrhli sme takéto spoločné systémové riešenie pre celý región - vzniklo združenie pre separovaný odpad a nakladanie s odpadom, ktoré dohliada na systémové separovanie odpadu a spoločne sa riešia vznikajúce problémy“. Firma ENVIGEOS Nitra s.r.o., ktorú založil zamestnanec univerzity v roku 1993 sa zaoberala v nadväznosti na jeho pôsobenie $\mathrm{v}$ akademickej sfére vývojom a výskumom $\mathrm{v}$ oblasti prírodných vied a poradenstvom v oblasti odpadového hospodárstva, až neskôr (1998) nakladaním s odpadmi a recykláciou triedených odpadov. S rastom firma postupne vyžadovala intenzívnejšie osobné nasadenie jej majitel'a a tak v roku 2010 rozviazal pracovný pomer s univerzitou. Ako uvádza , už som bol príliš zat’ažený povinnost'ami z praxe a tak som v roku 2010 zanechal svoje pôsobenie na univerzite. S univerzitou v̌̌ak spolupracujem dosial”. Firma má podpísanú rámcovú zmluvu o spolupráci s FZKI. V rámci nej firma spolupracuje s pedagógmi pri predkladaní projektov, na riešení záverečných prác, pri publikovaní výsledkov pracovníkov a študentov, organizuje besedy so študentmi a ministrom. Poznatky získané v spolupráci s firmou sú zapracované do učebných materiálov (skriptá, učebnica). Firma spolupracuje aj s okresnými úradmi (odbor starostlivosti o ŽP) a obcami. Napr. v spolupráci s pedagógmi SPU bola vypracovaná špeciálna metodika nakladania s odpadmi pre región.

K založeniu firmy 3 viedla nevyhnutnost' zabezpečit' služby praktickej výučby, výskumu, vývoja a realizácie odborných praxí študentov SPU. Hlavným dôvodom pre založenie podniku bola podnikatel'ská činnost' pol'nohospodárskeho podniku, vytvorit' experimentálnu bázu pre univerzitu a príprava absolventov pre ich úspešné uplatnenie na trhu práce. V prípade firmy 3 nešlo o individuálne rozhodnutie založit' firmu, ale o kolektívne rozhodnutie manažmentu univerzity. Nová firma vznikla odčlenením od univerzity v roku 2003 z dôvodu zmien $\mathrm{v}$ legislatíve, komplikovaného riadenia a ako aj nových príležitostí pre financovanie podniku.

\section{Kl’účové faktory, ktoré pôvodcu ovplyvnili pri vývoji a komercializácii technológie}

Respondenti firiem 1 a 2 sa zhodli, že pri vývoji a komercializácii technológie ako aj výsledkov výskumu ich ovplyvnili pozitívne predovšetkým osobná iniciatíva (resp. motivácie) a manažérske zručnosti. V prípade majitela firmy 2 to boli aj pozitívne vzory a riešenia odpadového hospodárstva $\mathrm{v}$ zahraničí (tzv. rolové modely združení pre separovaný odpad a nakladanie s odpadom) a existujúca spolupráca s obcami v NSK a neskôr aj so založeným Ponitrianskym združením obcí pre separovaný zber a nakladanie s odpadmi. V období založenia firmy (1993) neexistovala žiadna systémová univerzitná politika podpory komercializácie výsledkov výskumu a ani konkrétne podporné nástroje (pravidlá, smernice, postupy) alebo podporná infraštruktúra (transferové centrum, inkubátor a 
pod.). Firma 1 bola založená neskôr a proces komercializácie technológie zahŕňa zabezpečenie ochrany duševného vlastníctva. Nakol'ko univerzita v tom čase pripravovala vnútorné predpisy, ktoré upravujú oblast' duševného vlastníctva a proces jeho komercializácie, pôvodca musel riešit' väčšinu otázok a problémov spojených s ochranou novej technológie individuálne resp. s podporou CVTI. Transferové centrum bolo na SPU založené až v roku 2015 a jeho podpora sa prejavila až v neskoršej fáze komercializácie technológie (príprava licenčnej zmluvy). Pôvodca negatívne hodnotí obmedzený prístup k financovaniu, podporu zo strany univerzity ( $\mathrm{v}$ tom čase neexistovali jasné pravidlá, smernice a postupy), absentujúcu podpornú infraštruktúru, svoj status študenta $\mathrm{v}$ čase vývoja technológie a $\mathrm{v}$ počiatočnej fáze registrácie ochrany duševného vlastníctva (investoval a výstup je vlastníctvom SPU) a neochotu prijat' riziko zo strany SPU (tab. 4). Finančne proces zaistenia ochrany duševného vlastníctva prevzalo na seba CVTI. Respondent z firmy 3 dopíňa, že vlastný výskum na univerzite, ako aj transfer výsledkov vedecko-výskumnej činnosti do praxe, v súčasnom období stretáva s viacerými významnými bariérami (okrem uvedených v tab. 4). „Sú nimi predovšetkým útlm v polnohospodárstve, chýbajúca koordinácia výskumu a jeho rozdrobenost', vyššia rizikovost' aplikovaného výskumu v porovnani so základným výskumom, absentuje spätná väzba na reálne využitie poznatkov v praxi, $v$ porovnaní s predchádzajúcim obdobím (80-te roky) nizka intenzita (malý záujem) riešenia výskumných úloh na objednávku, rastúca konkurencia zahraničných firiem, ktoré realizujú vlastný výskum a na Slovensko dovážajú už nové technológie a hotové produkty."

Tab. 4: Bariéry vývoja novej technológie a komercializácie výskumu na SPU Table 4: Barriers of the new technology development and the commercialization of research results at the SUA

\begin{tabular}{|l|r|r|r|}
\hline \multicolumn{1}{|c|}{ Bariéry } & Firma 1 & Firma 2 & Firma 3 \\
\hline $\begin{array}{l}\text { absentujúce transferové centrum (počas vývoja } \\
\text { technológie) }\end{array}$ & $\mathrm{x}$ & & \\
\hline nedostatočne rozvinutá podporná infraštruktúra & $\mathrm{x}$ & $\mathrm{x}$ & \\
\hline byrokracia & $\mathrm{x}$ & $\mathrm{x}$ & \\
\hline obmedzený prístup k financiám & $\mathrm{x}$ & $\mathrm{x}$ & \\
\hline $\begin{array}{l}\text { zle nastavená interná politika univerzity vo vzt'ahu k } \\
\text { duševnému vlastníctvu }\end{array}$ & $\mathrm{x}$ & & \\
\hline negatívna percepcia kolegov, závist' & $\mathrm{x}$ & & \\
\hline neochota riskovat' zo strany univerzity & & $\mathrm{x}$ & \\
\hline slabá solventnost' obchodných partnerov & & $\mathrm{x}$ & \\
\hline pokles trhu resp. odvetvia & & $\mathrm{x}$ & \\
\hline $\begin{array}{l}\text { pomalost' reakcí́ univerzitného prostredia na } \\
\text { požiadavky praxe }\end{array}$ & & & \\
\hline
\end{tabular}

Zdroj: Interview so štatutármi firiem a pôvodcom patentu, 2017 
Zamestnancom univerzity chýba motivácia $\mathrm{k}$ hl'adaniu možností podiel'at' sa na transfere výsledkov ich výskumnej práce do praxe, niektoré činnosti (napr. poradenstvo, konzultácie), ktoré sú spojené s transferom poznatkov do praxe, sú časovo náročné a $\mathrm{v}$ podmienkach VPP je problémom paradoxne aj nedostatok kvalifikovanej pracovnej sily (ktorý zrejme súvisí s neochotou pracovat' za predložených pracovných podmienok).

\section{Podpora transferu výsledkov vedecko-výskumnej činnosti na SPU}

Respondenti vybraných firiem potvrdili opodstatnenost' a nevyhnutnost' existencie transferového centra, očakávajú však väčšiu angažovanost' univerzity pri zabezpečovaní transferu výsledkov vedecko-výskumnej činnosti ,viac zamestnancov, ktorí by zabezpečovali na SPU právnu a ekonomickú podporu“. Zo strany univerzity je potrebné jasné nastavenie politiky podpory transferu výsledkov výskumnej činnosti do praxe a prijatie rizika pri vývoji technológií a komercializácii výsledkov výskumu.

Významnou úlohou univerzity je motivovat' vedecko-výskumných pracovníkov k vývoju a transferu nových technológií, podporit' ich ochranu a komercializáciu v praxi. V rámci univerzitnej politiky podpory tvorby a ochrany duševného vlastníctva ,,by mala univerzita vytvorit' „,motivačný systém “, ktorý by definoval jasné kritériá hodnotenia výkonu, viedol by $k$ zodpovedajúcemu morálnemu a finančnému oceneniu výkonných pracovníkov a podporil by osobnú iniciativu zamestnancov v tejto oblasti “. Z realizovaných interview vyplynulo, že „podporit' iniciativu pri vytváraní, registrácii a ochrane predmetov duševného vlastnictva je možné cez posilnenie rozhodovacich procesov na univerzite, zjednodušenie administrativnych podmienok a procesov, zavedenie adresného motivačného systému zamestnancov a finančnú podporu procesu (registrácia) ochrany duševného vlastníctva zo strany univerzity“. „Momentálne nič nebráni zamestnancovi, aby požiadal o ochranu predmetu duševného vlastníctva, ktorý vytvoril, individuálne. "Niektorí z respondentov navrhujú v rámci motivačného mechanizmu zohl'adnit' časovú náročnost' práce na vývoji novej technológie $\mathrm{v}$ rámci pracovných povinností ,pedagógovia, ktorí sa podielajú na vývoji technológie pre prax by mali mat' znižený počet vyučovacích hodín, dostat' priestor na svoju prácu“. Univerzita by mala zamestnancov, ktorí sa podiel'ajú na vývoji novej technológie a transfere výsledkov vedecko-výskumnej činnosti do praxe motivovat' aj finančne - formou odmeny. Predpokladá sa, že univerzita vyčlení vlastné zdroje na vývoj prototypov a pomôže pri diseminácii informácií o vývoji a dostupnosti novej technológie $\mathrm{v}$ súkromnom sektore. Jej d'alšou dôležitou úlohou v procese podpory transferu výsledkov vedecko-výskumnej činnosti do praxe je zaistit' účinný marketing a propagáciu. Za dôležité považujú respondenti tiež siet’ovanie - nadväzovanie spolupráce s firmami, ktoré majú záujem o experimentálne činnosti. 
Objavili sa tiež odporúčania smerom $\mathrm{k}$ lepšej koordinácii rezortných politík na národnej úrovni najmä vzájomnému zosúladeniu ich záujmov pri podpore a financovaní výskumu (napr. v nastavení podmienok na financovanie projektov).

\section{Záver}

Na základe zistení uvedených $\mathrm{v}$ príspevku zostáva záverom zodpovedat' otázky: Aké sú spin-off firmy, ktorých vznik podnietila SPU? Aké faktory ovplyvnili ich založenie? Predstavujú novodobý fenomén? Podporuje SPU ich zakladanie? Skúmané firmy sú spin-off firmami v zmysle flexibilnejšieho vymedzenia. Boli založené univerzitou alebo zamestnancom univerzity, ktorí pritom zanechali pôvodnú organizáciu za účelom založenia právne a technicky samostatnej jednotky. Univerzita tieto firmy podporovala $v$ úvodnej fáze založenia firmy resp. niektoré $\mathrm{z}$ firiem podporuje dosial'. Firmy pôsobia $\mathrm{v}$ rôznych odvetviach: IKT, marketing, odpadové hospodárstvo a pol'nohospodárstvo. Ich činnost' je úzko previazaná na výskum konkrétnych pracovísk SPU. Tieto firmy sa niektorými znakmi líšia od ortodoxne vymedzených spin-off napr. univerzita nemá majetkovú účast' $\mathrm{v}$ existujúcej firme, pôvodcovia duševného vlastníctva sa nepodiel'ajú priamo na činnosti firmy, používaná technológia resp. výsledný produkt nie je chráneným predmetom duševného vlastníctva (tab.3). Založenie skúmaných spin-off ovplyvnili predovšetkým osobná iniciatíva a manažérske zručnosti pôvodcov myšlienky, príklady dobrej praxe $\mathrm{v}$ zahraničí, spolupráca $\mathrm{s}$ partnermi v praxi a výskumná činnost' na pracoviskách. V období objavenia novej technológie resp. založenia skúmaných firiem na univerzite neexistovala systémová univerzitná politika podpory komercializácie výsledkov výskumu a ani konkrétne podporné nástroje (pravidlá, smernice, postupy) alebo podporná infraštruktúra (transferové centrum, inkubátor a pod.). Napriek tomu spin-off firmy ojedinele a bez koordinácie zo strany univerzity, vznikali už v predchádzajúcom období (90-te roky) a nemožno ich považovat' len za novodobý fenomén. K výraznejšej podpore komercializácie výsledkov výskumnej činnosti na univerzite došlo až po roku 2010. V období rokov 2012-2015 podnikla univerzita konkrétne kroky k vytvoreniu centralizovanej štruktúry inovačného a transferového systému. Výsledkom riešenia viacerých projektov bolo založenie Výskumného centra AgroBioTech a Transferového centra SPU. Na univerzite boli nastavené vnútorné pravidlá pre podporu komercializácie výsledkov výskumu: Smernica o podnikatel'skej činnosti zamestnancov, Manuál interných procesov pre riadenie a komercializáciu duševného vlastníctva v praxi, Smernica o ochrane duševného vlastníctva a Smernica o transfere technológií, ktoré postupne nadobudli platnost' (Chreneková et al., 2017). Respondované firmy potvrdili význam TC pre zintenzívnenie transferu výsledkov výskumnej činnosti do praxe. Okrem toho upozorňujú na d'alšie potrebné kroky pri koncipovaní univerzitnej politiky podpory transferu: potrebu motivovat' zamestnancov $\mathrm{k}$ vývoju a transferu nových 
technológií, podporit' ich ochranu a komercializáciu, prijat riziko pri vývoji technológií a komercializácii výsledkov výskumu, finančne podporit' vývoj prototypov $\mathrm{v}$ laboratórnych podmienkach, pomáhat' pri diseminácii informácií $\mathrm{o}$ vývoji a dostupnosti novej technológie v súkromnom sektore, zabezpečit' účinný marketing a siet’ovanie s firmami, ktoré majú záujem o experimentálne činnosti.

\section{Pod'akovanie}

Príspevok bol spracovaný v rámci projektu UNIREG (Univerzity a ekonomický rozvoj regiónov) č. APVV-14-0512.

\section{Literatúra}

BATHELT, H. - KOGLER, D. F. - MUNRO, A. K. 2010. A knowledge-based typology of university spin-offs in the context of regional economic development. In Technovation. ISSN 0166-4972, 2010, vol. 30, no. 9-10, pp. 519-532.

BELLINI, E. et al. 1999. The role of academic spin-offs in connecting technological local assets in regional contexts: A comparative analysis of Italian and Swedish cases. In 44th ICSB Conference.

BERNARDT, Y. et al. 2002. Spin-off start-ups in the Netherlands. In EIM Business and Policy Research, 2002.

ČOREJ, J. a kol. 2006. Univerzity, priemysel a partnerstvo. Doktorandské štúdium a transfer poznatkov. Žilina: EDIS ŽU, 2006. ISBN 80-8070-526-7.

ČOREJOVÁ, T. - ROSTÁŠOVÁ, M. 2016. University-Industry partnership in the context of regional and local development. In Information Technology Based Higher Education and Training (ITHET), 2016 15th International Conference on. IEEE, 2016. pp. 1-6.

DJOKOVIC, D. - SOUITARIS, V. 2008. Spinouts from academic institutions: a literature review with suggestions for further research. In The Journal of Technology Transfer. vol. 33, no. 3, pp. 225-247.

CHRENEKOVÁ, M. et al. 2017. Inovačný ekosystém Slovenskej pol'nohospodárskej univerzity a jej spolupráca s praxou. In $X X$. mezinárodní kolokvium o regionálních vědách. Sborník př́spěvků. Brno: Masarykova univerzita, 2017. s. 1-5. ISBN 978-80-210-8587-9.

JANOVČÍK, M. - HERČKO, J. - KLACKOVÁ, M. 2014. Štúdia na podporu inovatívneho podnikania ako nástroja zvyšovania zamestnanosti v Slovenskej republike. Žilina. 2014. $230 \mathrm{~s}$.

KLÍMOVÁ, V. 2013. Inovační infrastruktura v Moravských regionech. In Klímová, V., Žítek, V. (eds.) 16th International Colloquium on Regional Sciences. Conference Proceedings. Brno: MU, 2013. s. 198-204. ISBN 978-80210-6257-3. 
KLOFSTEN, M. - JONES-EVANS, D. 2000. Comparing academic entrepreneurship in Europe-the case of Sweden and Ireland. In Small Business Economics. vol.14, no. 4, pp. 299-309.

NOSKOVIČ, J. 2018. Transfer technológií. Príručka pre tréning 29. máj 2018 SPU v Nitre- VPP Kolíňany. CVTI, 2018. $35 \mathrm{~s}$.

PIRNAY, F. et al. 2003. Toward a typology of university spin-offs. In Small business economics. vol. 21, no. 4, pp. 355-369.

PATTNAIK, P. N. - PANDEY, S. C. 2014. University Spinoffs: What, Why, and How?. In Technology Innovation Management Review. vol. 4, no. 12.

RYDVALOVÁ, P. Role univerzit při vzniku inovativních firem. Liberec: Technická univerzita v Liberci, 2011. 57 s. ISBN 9788087184158.

SOETANTO, D. - VAN GEENHUIZEN, M. 2015. Getting the right balance: University networks' influence on spin-offs' attraction of funding for innovation. In Technovation. no. 36, pp. 26-38.

\section{UNIVERSITY SPIN-OFF ENTERPRISES: WHAT'S THEIR NATURE? (CASE STUDY OF THE SUA IN NITRA)}

\section{Summary}

The aim of the paper was to identify existing and potential spin-off firms in the environment of the Slovak University of Agriculture in Nitra, their specifics compared to orthodox defined spin-off firms, the conditions for their establishment, to examine the process of commercialization of intellectual property from the birth of the idea to the establishment of own company in selected spin-off companies. Examined firms are spin-off companies in terms of more flexible definition. They were founded by university or university staff, leaving behind the original organization to establish a legally and technically separate unit. The university supported these firms in the seed phase, some are still supported. Companies are active in various sectors: ICT, marketing, waste management and agriculture. Their activity is closely linked to the research of specific SPU departments. These enterprises differ in some characteristics from orthodoxdefined spin-offs, for example, the university does not have a stake in an existing firm, the intellectual property owners are not directly involved in the company's activities, the technology used, resp. the resulting product is not a subject of intellectual property protection. The establishment of these spin-offs was influenced in particular by the personal initiative and managerial skills of founders, examples of good practices from abroad, co-operation with partners in practice, and research activity at university departments. At the time of new technology discovery, foundation of this spi-offs was not provided by a systemic university policy to support the commercialization of research results, specific support instruments (rules, guidelines, procedures), or support infrastructure (transfer 
center, incubator, etc.). Nevertheless, spin-offs were occasionally created without university support in the previous period (90s) and thus cannot be regarded as a modern phenomenon. The university began to increasingly support commercialization after 2010. In the period 2012-2015 University has taken concrete steps to create a centralized structure of innovation and transfer system. The result of several projects was the establishment of the AgroBioTech Research Center and the Center for Transfer Technology. The internal policies for promoting the commercialization of research results (the Directive on Employee Entrepreneurship, the Manual of Internal Procedures for the Management and Commercialization of Intellectual Property in Practice, the Intellectual Property Protection Directive and the Directive of Technology Transfer) have been set up at the university which have gradually entered into force. Responded companies have confirmed the importance of Center for Transfer Technology for stepping up the transfer of research results into practice. They also draw attention to the further steps needed to design a university transfer support policy: the need to motivate researchers to develop and transfer new technologies, promote their protection and commercialization, take risks in developing technologies and commercialization of research results, financially support the development of prototypes at the laboratory stage, assist in the dissemination of information on the development and availability of new technology in the private sector, to ensure effective marketing and networking with companies in the private sector who could be interested in university knowledge.

\section{Doc. Ing. Jana Jarábková, PhD.}

Ing. Marcela Chreneková, PhD.

Slovenská pol'nohospodárska univerzita v Nitre

Trieda A Hlinku 2, 94976 Nitra

E-mail: jana.jarabkova@uniag.sk, marcela.chrenekova@uniag.sk 